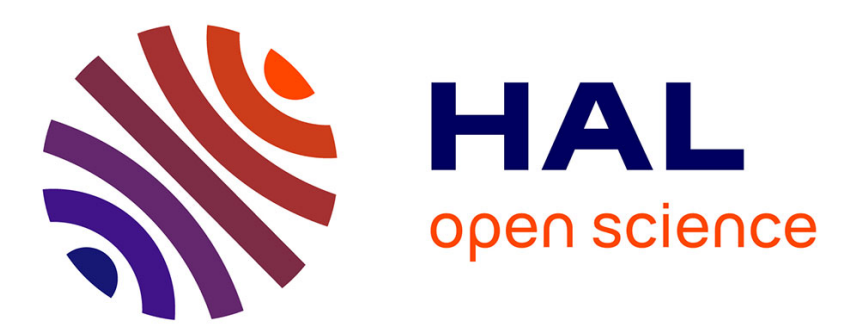

\title{
Gap junction communication between chromaffin cells: the hidden face of adrenal stimulus-secretion coupling
}

Nathalie C. Guérineau

\section{To cite this version:}

Nathalie C. Guérineau. Gap junction communication between chromaffin cells: the hidden face of adrenal stimulus-secretion coupling. Pflügers Archiv European Journal of Physiology, 2018, Epub ahead of print. 10.1007/s00424-017-2032-9 . inserm-01575237

\section{HAL Id: inserm-01575237 https://www.hal.inserm.fr/inserm-01575237}

Submitted on 21 Aug 2017

HAL is a multi-disciplinary open access archive for the deposit and dissemination of scientific research documents, whether they are published or not. The documents may come from teaching and research institutions in France or abroad, or from public or private research centers.
L'archive ouverte pluridisciplinaire $\mathbf{H A L}$, est destinée au dépôt et à la diffusion de documents scientifiques de niveau recherche, publiés ou non, émanant des établissements d'enseignement et de recherche français ou étrangers, des laboratoires publics ou privés. 
3 Gap junction communication between chromaffin cells: the hidden face of adrenal

4 stimulus-secretion coupling

5 Nathalie C. Guérineau

6 IGF, CNRS, INSERM, Univ. Montpellier, France

7

8 Correspondence should be addressed to Nathalie C. Guérineau, Institut de Génomique

9 Fonctionnelle, CNRS UMR5203; INSERM U1191; Université Montpellier, 141 rue de la

10 Cardonille, 34094 Montpellier CEDEX 05, France. Tel: 33-4-34-35-92-50; E-mail:

11 nathalie.guerineau@igf.cnrs.fr

12 ORCID: http://orcid.org/0000-0003-2517-4210

13

14 Keywords: gap junctions, chromaffin cells, catecholamine secretion, adrenal stimulus-

15 secretion coupling

16

This article is published as part of the Special Issue on [Focus on adrenal chromaffin cells : from molecules to body function] 


\section{Abstract}

17 From birth to death, catecholamine secretion undergoes continuous adjustments, allowing the organism to adapt to homeostasis changes. To cope with these stressful conditions, the neuroendocrine cells of the adrenal medulla play an immediate and crucial role. Chromaffin cell-driven catecholamine release is chiefly controlled by a neurogenic command that arises

21 from the sympathetic nervous system, which releases acetylcholine at the splanchnic nerve terminal-chromaffin cell synapses. In addition to receiving several synaptic inputs individually, chromaffin cells are coupled by gap junctions. This raises interesting questions about the usefulness and the role of the gap junctional coupling within the chromaffin tissue, considering that secretory function is efficiently completed by the neurogenic pathway. The findings that gap junctions contribute to catecholamine secretion, both ex vivo and in vivo, provide some early answers, but their involvement in other cellular functions still remains unexplored. This review summarizes the molecular and physiological evidence that gap junctions can act either as an accelerator or a brake of stimulus-secretion coupling, and discusses this functional plasticity in the context of specific needs in circulating

31 catecholamine levels. It introduces the concept of gap junctions as sympathetic activity sensors and guardians of the functional integrity of the chromaffin tissue. 
Intimate crosstalk between cell populations crucially contributes to the maintenance of tissue syncytial function within an organ, and more generally body homeostasis. In this context, by promoting the exchange of biological signals between adjacent cells [1], gap junctionmediated intercellular communication plays a key role in many cell functions. Hormone secretion from endocrine/neuroendocrine tissues is one of those functions, and as extensively reviewed in two recent articles [16,27], it is unequivocal that gap junctional signaling between secretory cells contributes to control hormone release. This article focuses on the adrenal chromaffin tissue, which is responsible for the secretion of catecholamines. Rather than being a narrative review on adrenomedullary gap junctions, the article addresses the author's personal opinion on the benefit for chromaffin cells to be both synaptically connected to an external neuronal command and locally coupled by gap junctions.

What is the added value for an adrenal chromaffin cell to be coupled by gap junctions to other chromaffin cells? Is this coupling relevant for hormone secretion? If yes, how does gap junctional communication between chromaffin cells interact with the synaptic control of catecholamine secretion? Many questions are raised by the presence of gap junctions in the adrenal medullary tissue, and in chromaffin cells in particular. And finally, do we have answers?

As a preamble to this review, the author draws the reader's attention to the paucity of studies dedicated to gap junction-mediated communication in the adrenal medulla, although medullary gap junctions were anatomically identified more than thirty-five years ago [12]!

The secretory role of gap junctions between chromaffin cells: for a long time suspected, only recently disclosed

Attempting to elucidate the enigmatic role of gap junctions in the adrenal medullary tissue is not a recent issue. In a seminal study describing the presence of ultrastructurally-identified 
gap junction plaques in the adrenal medulla of various species [12], the authors stated that "... Since the triggering of hormonal release is achieved at synaptic junctions, there is no need of coupling between chromaffin cells to allow the exchange of a stimulating agent. It seems likely that gap junctions are involved in another process...". At the same time, a study performed in rat pancreatic islets, an endocrine tissue sharing multiple features with the adrenal chromaffin tissue, reported an increase in gap junction number between beta-cells in response to stimulation of insulin secretion [28]. This opened a wide research field on the contribution of gap junctional communication between endocrine/neuroendocrine cells to their secretory function.

Do adrenal medullary gap junctions contribute to catecholamine secretion? A simple question in theory, but with more than one answer, thus demonstrating the intricate contribution of gap junctional communication to the adrenal stimulus-secretion coupling. Mechanistically, by favoring the diffusion of instructive signals (ions, second messengers, cell metabolites...) between cells [1], gap junction channels are decisive determinants engaged in cell network function through the collective organization of cell activity, and more generally in the regulation of physiological functions. It was thus rational to envision that adrenal medullary gap junctions could be involved in the regulation of catecholamine secretion.

What evidence, even indirect, do we have? The fraction of gap junction-coupled chromaffin cells, the connexin composition of junctional channels and the robustness of the electrical coupling vary by species, gender, age, cholinergic activity and stress conditions ([5,7] for reviews) (discussed below). Of particular interest is that all these situations are associated with distinct catecholamine needs and demands, arguing for a possible contribution of gap junctions to hormone release. Along the same lines, the cumulative observations that i) rat chromaffin cells are more frequently and more robustly coupled in females $[24,8,7]$, ii) 
Cx36 and Cx43 proteins are more expressed in the adrenal medulla of female mice [15], iii) stress responses (increased E plasma levels) are higher in females than in males rats $[22,42]$, and iv) basal catecholamine amounts assayed in adrenal venous blood are enhanced upon gap junction blockade [10] indirectly plead for a possible role of adrenal gap junctions in catecholamine release.

The hypothesis that gap junctions might be conduits allowing propagation of electrical signals between chromaffin cells has been early proposed [4,17]. Many years later, the experimental demonstration came from recording of either electrical "echoes", which correspond to action potentials in neighbouring cells evoked by the depolarization of the patch-clamped cell $[30,15]$ or junctional currents in dual-patched chromaffin cell pairs [24]. Whether this electrical communication between chromaffin cells can support catecholamine release was initially disclosed ex vivo by records of exocytotic currents in cells neighboring a stimulated cell in rat acute adrenal slices [24], and more recently in vivo in response to a high frequency splanchnic nerve stimulation in anaesthetized mice [10]. Nevertheless, in another study performed in mouse adrenal slices, catecholamine secretion evoked by a transmural electrical stimulation of the chromaffin tissue was reported to be independent on gap junctional pathway [32]. At first glance, this could appear as an inconsistency, but further examination of the data reveals a subtle and complex involvement of gap junction in the hormone secretion. Whether or not gap junctions contribute to the secretory process seems largely dictated by the degree of sympathetic activation of the adrenal medullary tissue, although this is difficult to compare between studies. Upon modest activation of chromaffin cells (mimicking the basal sympathetic tone), gap junction coupling does not significantly contribute to hormone release $[32,10]$. Conversely, in response to a robust stimulation of the chromaffin tissue (mimicking an enhanced sympathetic tone as, for example, found under stress conditions), the expression of medullary gap junctions is upregulated $[6,8,10]$ and the 
biological signals exchanged between coupled cells unequivocally participate in

109 catecholamine release [10]. Providing further support for this is the demonstration that

110 pituitary adenylate cyclase-activating polypeptide (PACAP), a splanchnic-derived peptide

111 transmitter that is mainly released during elevated nerve firing [36], enhances gap junction-

112 mediated electrical coupling in the mouse adrenal medulla [15]. Together, these studies unveil

113 the sympathetic activity-dependent contribution of adrenal medullary gap junctional

114 communication in catecholamine secretion. This later point may be decisive in decoding the

115 functional role of gap junctions in the adrenal medullary tissue, and it deserves to be kept in

116 mind not only when reading this review but more generally when engaging experiments on

117 the role of gap junctions in hormone release from neuroendocrine tissues.

119 Adrenal medullary gap junctions: a highly and finely regulated cell-cell communication

120 route devoted to continuously adjusting catecholamine secretion to body needs

121 Deciphering the molecular, cellular and tissue mechanisms regulating hormone secretion is

122 still a topical challenge for scientists engaged in the field of

123 endocrinology/neuroendocrinology. Regarding the adrenal medullary tissue, it has been long

124 reported that catecholamine release primarily relies on synaptic neurotransmission between

125 splanchnic nerve endings and chromaffin cells [39]. Since functional gap junctions were

126 described between secretory cells [24], the situation became more complicated and it is no

127 longer tenable to investigate the mechanisms of hormone release without considering the

128 intricate interactions between chemical and electrical communication.

130 1- Prevalent gap junctional communication between chromaffin cells in neonates: cell-cell

131 coupling for survival 
132 In adrenal medulla, the prevalence of gap junctional communication between chromaffin cells

133 during the perinatal period is remarkable from a physiological point of view. To cope with

134 hypoxic stress triggered during parturition, the newborn organism secretes massive amounts

135 of epinephrine (E) and norepinephrine (NE). Because the neurogenic control of the adrenal

136 catecholamine secretion is not competent at birth, at least in the rat and mouse $[35,18]$, the

137 prevalent gap junction coupling observed in rodent neonates [25,23], by supporting the

138 propagation of signaling molecules between the secretory cell network, likely sustains the

139 hormone secretion that is essential to survival (Figure 1).

140

141 2- Gradual reduction of gap junctional communication between chromaffin cells in postnatal

142 animals: a crucial mechanism for acquiring the neurogenic control of catecholamine

143 secretion

144 After experiencing a secretory role in neonates, gap junctions between chromaffin cells

145 decline in parallel with the development of neuronal synaptic connections during the first

146 postnatal weeks (Figure 1). In this context, we identified the proteoglycan agrin as a primary

147 factor promoting the switch from electrical to chemical synapses [23]. Indicating how helpful,

148 if not indispensable the contribution of gap junctions is to the regulation of catecholamine

149 secretion in early life, this study shows that, in the adrenal medullary tissue, like in the central

150 nervous system [20], electrical (gap junction-mediated) and chemical (synapse-mediated)

151 communication pathways are functionally interconnected and exhibit coordinated plasticity

152 mechanisms. This mutual and reciprocal interaction actively contributes to set the respective

153 tone of the neurogenic and non-neurogenic control of chromaffin cell function. This crosstalk

154 is of a particular relevance not only in young animals for the establishment of the neurogenic

155 control of catecholamine secretion, but also, as discussed below, in adults in response to

156 physiological (acute stress) or pathological (chronic stress and related diseases) episodes. 
158 The crosstalk between gap junctional coupling and synaptic communication is not restricted

159 to the perinatal period. Conditions leading to an acute or a chronic decrease in the cholinergic

160 neurotransmission between splanchnic nerve terminals and chromaffin cells favor the re-

161 expression of functional gap junctions between the secretory cells (Figure 2). This was

162 reported in response to both a pharmacological blockade of postsynaptic nicotinic receptors

$163[25,9]$ or a surgical splanchnectomy [25]. Interestingly and illustrating the guardian role of

164 chromaffin cell gap junctions on adrenal medulla function is the fact that the functional gap

165 junction signaling takes place less that $30 \mathrm{~min}$ after $\mathrm{nAChR}$ inhibition. At present, the

166 underlying mechanism is not fully elucidated but connexin/connexon trafficking seems to be

167 involved [25]. The fast kinetic of the re-appearance of functional gap junctions indicates that,

168 in conditions of normal synaptic transmission, the junctional communication between

169 chromaffin cells is silenced rather than suppressed.

4- Tonic brake of the cholinergic system on gap junctional coupling under low sympathetic

tone: a mechanism contributing to the maintenance of basal catecholamine secretion

In vivo, basal catecholamine release is associated with low frequency splanchnic nerve

174 discharges. The blockade of adrenal gap junctional communication by the uncoupling agent

175 carbenoxolone (CBX) does not impact the amounts of E and NE released in adrenal venous

176 blood in response to low frequency splanchnic nerve stimulation in anaesthetized mice [10].

177 This suggests the existence of inhibitory mechanisms that silence gap junction channel

178 function, an issue largely overlooked. Our group addressed it a decade ago in rat acute adrenal

179 slices, and to the best of our knowledge, no new findings have contributed to this research

180 field to date. As mentioned in the previous chapter, the gap junctional communication

181 between chromaffin cells is up-regulated (increased number of dye- or electrically-coupled 
182 chromaffin cells) in response to the acute pharmacological blockade of post-synaptic nicotinic

183 acetylcholine receptors [25,9] or in a denervated gland [25] (figure 2). This led us to identify

184 the cholinergic system, via sympathetic tone, as one of the determinants operating a tonic

185 brake over chromaffin cell gap junctions, as reported at the same time for the glutamatergic

186 system over the spinal motor neuron gap junctions [29]. What could be the physiological

187 relevance of such an inhibitory control? The establishment of a low catecholamine secretory

188 rate under basal condition is crucial to maintain body homeostasis. Therefore, dampening the

189 gap junctional communication between secretory cells would finely tune basal catecholamine

190 secretion by reducing chromaffin tissue excitation, thus contributing to the low secretion rate

191 associated with the "rest and digest" state of energy storage. Reflecting how intricate is the

192 contribution of gap junctions to hormone secretion is blockade of gap junctional

193 communication (either pharmacologically or genetically by silencing connexin-encoding

194 genes) tends to enhance basal catecholamine release [10], as also observed for insulin release

195 from $\beta$-cell in pancreatic islets $[3,33]$.

5- Up-regulation of gap junctional communication between chromaffin cells: a functional remodeling to boost catecholamine secretion in response to stress

199 In its early phase, the stress response consists of a heightened sympathetic tone and increased 200 catecholamine secretion. Do gap junctions between chromaffin cells contribute to this, and if 201 so, how? The few studies available to date were performed both ex vivo in acute adrenal slice $202[6,8,15]$ and in vivo in anaesthetized animals [10], and they unequivocally converge toward an 203 increased gap junctional communication between secretory cells (Figure 1). The underlying 204 mechanisms still remain largely unexplored, and the facts that i) acetylcholine (ACh) released 205 at the splanchnic nerve-chromaffin cell synapse can bind both nicotinic and muscarinic 206 receptors and ii) non-cholinergic neurotransmitters are co-released with ACh upon robust 
splanchnic nerve discharges [40] complicate the situation. The current view on the respective roles of nAChRs and mAChRs states that the acute activation of nAChRs, as occurs during episodes of stress, co-operates with gap junctional signaling to promote the spread of excitation within the chromaffin tissue. Concerning mAChRs, the muscarinic regulation of

211 chromaffin cell gap junctions has been proposed, with the hypothesis that muscarine could 212 increase gap junction coupling between chromaffin cells [31]. As discussed in [14], mAChRs, 213 by their extrasynaptic distribution, require intense and/or prolonged synaptic activity (as observed during stress episodes) to be activated, and thus may act in concert with other neurotransmitters released upon sustained sympathetic discharges to modulate gap junctional 216 communication between secretory cells and to enhance catecholamine secretion. Among the 217 non-cholinergic neurotransmitters co-secreted with ACh, PACAP is undoubtedly one of the 218 most relevant factors from a physiological point of view [36,37]. Beyond its secretagogue 219 action on catecholamine secretion [41,13,21], PACAP enhances gap junction-mediated 220 electrical coupling and the subsequent spread of electrical excitation between mouse 221 chromaffin cells [15]. Mechanistically, the stress condition correlates with up-regulation of Cx36 and $\mathrm{Cx} 43$ expression $[8,15]$, the two main gap junction proteins expressed in the rat adrenal medulla [24], and perhaps more importantly with the appearance of a robust and extended electrical coupling between coupled cells [8]. Does this enhanced coupling impact hormone secretion? The answer is yes, but with some distinctions. Indeed, the in vivo gap junction blockade in unstressed animals reduces only NE secretion evoked by high frequency splanchnic nerve stimulation, whereas the same experiments conducted in stressed animals lessens both E and NE release [10]. Nevertheless and even though the remodeling of gap junction signaling 230 significantly contributes to boost catecholamine secretion upon stress conditions, it is likely 231 that additional mechanisms also contribute to this rise in hormone secretion. 
235 Beyond the beneficial effect of catecholamine secretion elicited in response to acute stress

236 episodes, sustained and/or repetitive catecholamine rises (in response to chronic stressful

237 situations for example) can have deleterious outcomes [38] and are well-known risk factors

238 for chronic diseases. This is particularly the case for arterial hypertension, as unveiled by the

239 elevated blood pressure observed in response to chronic infusion of $E$ in rat $[19,34]$ or in

240 chronically cold stressed rats [11]. Because gap junctions between chromaffin cells contribute

241 to catecholamine secretion in physiological conditions, it is likely that they are also involved

242 in pathological circumstances. But again, this research field is largely unexplored.

Consistent with the vision of a multifaceted intercellular communication route, we

244 recently provide evidence that a chronic hypertensive environment remodels the gap

245 junctional coupling between chromaffin cells. In the spontaneously hypertensive rat (SHR)

246 used as a model of chronic elevated blood pressure, the number of coupled chromaffin cells is

247 reduced (Figure 2). What could be the relevance of such a decrease in gap junctional

248 coupling? A heightened sympathetic tone is a hallmark of chronic arterial hypertension. The

249 resulting phasic activation of the splanchnic nerve endings increases the cholinergic

250 stimulation weight onto chromaffin cells, with potentially damaging consequences. We

251 therefore propose that the dampening of the gap junctional communication between secretory

252 cells would be an adaptive mechanism devoted to the protection of adrenal medullary tissue,

253 and body homeostasis, against the deleterious effects of redundant elevated catecholamine

254 secretion and associated blood pressure elevation. Although experienced in a different

255 context, our observation that the gap junction coupling probability between chromaffin cells

256 decreases in response to a pharmacologically enhanced cholinergic activity [7] reinforces our 
hypothesis. Interestingly, it is of note that in insulin-secreting pancreatic tissue, Cx36 expression between beta-cells decreases in response to chronic glucose elevation [2]. Together, we propose that, more generally, under pathological conditions associated with redundant elevated hormone levels (arterial hypertension, hyperinsulinemia associated with type 2 diabetes, with obesity...), gap junctions between endocrine/neuroendocrine cells contribute to damper intercellular communication, aiming at protecting body homeostasis and helping the organism to cope with a chronic deleterious environment. Beyond secretory function, this working hypothesis might be extended to other cell functions (contraction, neural signal propagation...).

\section{Adrenal medullary gap junctions: other functions and open questions}

As stated in the introduction, very few studies have been focused on gap junctions between chromaffin cells, and therefore there is to date more unanswered than answered questions. Rather than providing an exhaustive list of open questions, I chose to emphasize some

271 stimulating issues relevant for people engaged in the study of gap junctions in endocrine/neuroendocrine tissues.

A first set of queries relates to gap junction/connexin expression. Do gap junctions differently couple E- and NE-secreting chromaffin cells? And if so, how? Given that i) the gap junction blocker carbenoxolone distinctively affects $\mathrm{E}$ and NE secretion, both under basal and stimulated conditions [10], ii) gap junctional coupling is distinctly regulated by nicotinic and muscarinic agonists and iii) mAChRs are more concentrated in NE cells than in E cells

278 [43], unraveling this issue will certainly contribute to the better understanding of the individual role of gap junctions in $\mathrm{E}$ and $\mathrm{NE}$ secretion. Elucidating the respective role of $280 \mathrm{Cx} 36$ and Cx43, two connexins expressed in the chromaffin tissue, is also a challenging issue. 281 Bearing in mind that when engaged in a cell-cell communication pathway, the gap junction 
channels display distinct biophysical properties in terms of voltage dependency, unitary conductance, charge selectivity and regulatory mechanisms, it is likely that chromaffin cell clusters coupled by $\mathrm{Cx} 36$ or $\mathrm{Cx} 43$ will not have the same ability to modulate the secretory process.

A second set of still unsolved questions deals with the involvement of connexin in gap junction channel- and hemichannel-independent functions, a rapidly developing topic in the gap junction research field. As postulated by Grynszpan-Wynograd and Nicolas in a paper published in 1980 [12], "it seems likely that gap junctions are involved in another process, e.g. recycling of the plasma membrane after exocytosis, or synthesis procedure of catecholamines or chromogranins...". In light of recent studies, connexins via channelindependent mechanisms can contribute to cell motility and migration by regulating cell-cell adhesion, interactions with the cytoskeleton, and activation of intracellular signaling pathways [26,44]. This stimulating topic at the border between Cell Biology and Neurophysiology remains to be addressed in the adrenal medulla.

\section{Concluding remarks: Chromaffin cell gap junctional coupling is an intra-adrenal}

guardian devoted to finely tune catecholamine secretion and to secure body homeostasis,

\section{but not exclusively....}

Although their role has long been remained elusive, it is now indisputable that gap junctions contribute to secretory output, the primary function of the adrenal medulla. In this context, gap junctions between adrenal chromaffin cells underlie a remarkable degree of plasticity, as they continuously remodel to adjust the number of coupled cells, and the strength of the intercellular coupling, to the physiological/pathological context. The continuous and reciprocal dialogue between sympathetic synaptic activity and gap junction-mediated 
307 intercellular communication guarantees maintenance of chromaffin tissue syncytial function.

308 Notably, such interplay allows catecholamine secretion to be finely tuned to body needs.

309 However, and even if gap junctions between chromaffin cells appear to be primarily involved

310 in secretory function, the intercellular coupling does not necessarily relate to the secretory

311 function. This issue opens up a very exciting research field, with wide-ranging implications

312 for endocrine/neuroendocrine function.

\section{References}

316 1. Alexander DB, Goldberg GS (2003) Transfer of biologically important molecules between cells through gap junction channels. Curr Med Chem 10:2045-2058. PMID: 12871102.

2. Allagnat F, Martin D, Condorelli DF, Waeber G, Haefliger JA (2005) Glucose represses connexin36 in insulin-secreting cells. J Cell Sci 118:5335-5344. doi: 10.1242/jcs.02600. PMID: 16263767.

322 3. Benninger RK, Head WS, Zhang M, Satin LS, Piston DW (2011) Gap junctions and other mechanisms of cell-cell communication regulate basal insulin secretion in the pancreatic islet. J Physiol 589:5453-5466. doi: 10.1113/jphysiol.2011.218909. PMID:

4. Cena V, Nicolas GP, Sanchez-Garcia P, Kirpekar SM, Garcia AG (1983) Pharmacological dissection of receptor-associated and voltage-sensitive ionic channels involved in catecholamine release. Neuroscience 10:1455-1462. PMID: 6320053.

5. Colomer C, Desarmenien MG, Guerineau NC (2009) Revisiting the stimulus-secretion coupling in the adrenal medulla: role of gap junction-mediated intercellular 
communication. Mol Neurobiol 40:87-100. doi: 10.1007/s12035-009-8073-0. PMID: 19444654.

6. Colomer C, Lafont C, Guerineau NC (2008) Stress-induced intercellular communication remodeling in the rat adrenal medulla. Ann N Y Acad Sci 1148:106-111. doi: 10.1196/annals.1410.040. PMID: 19120097.

7. Colomer C, Martin AO, Desarmenien MG, Guerineau NC (2012) Gap junction-mediated intercellular communication in the adrenal medulla: An additional ingredient of stimulus-secretion coupling regulation. Biochim Biophys Acta 1818:1937-1951. doi:10.1016/j.bbamem.2011.07.034. PMID: 21839720.

8. Colomer C, Olivos Ore LA, Coutry N, Mathieu MN, Arthaud S, Fontanaud P, Iankova I, Macari F, Thouennon E, Yon L, Anouar Y, Guerineau NC (2008) Functional remodeling of gap junction-mediated electrical communication between adrenal

9. Colomer C, Olivos-Ore LA, Vincent A, McIntosh JM, Artalejo AR, Guerineau NC (2010) Functional characterization of alpha9-containing cholinergic nicotinic receptors in the rat adrenal medulla: implication in stress-induced functional plasticity. $\mathrm{J}$ Neurosci 30:6732-6742. doi: 10.1523/JNEUROSCI.4997-09.2010. PMID: 20463235.

10. Desarmenien MG, Jourdan C, Toutain B, Vessieres E, Hormuzdi SG, Guerineau NC (2013) Gap junction signalling is a stress-regulated component of adrenal neuroendocrine stimulus-secretion coupling in vivo. Nat Commun 4:2938. doi: 10.1038/ncomms3938. PMID: 24356378.

11. Fregly MJ, Kikta DC, Threatte RM, Torres JL, Barney CC (1989) Development of hypertension in rats during chronic exposure to cold. J Appl Physiol (1985) 66:741749. PMID: 2708203. 
12. Grynszpan-Wynograd O, Nicolas G (1980) Intercellular junctions in the adrenal medulla: a comparative freeze-fracture study. Tissue Cell 12:661-672. PMID: 7209957.

13. Guo X, Wakade AR (1994) Differential secretion of catecholamines in response to peptidergic and cholinergic transmitters in rat adrenals. J Physiol 475:539-545. PMID: 8006835.

14. Hill J, Chan SA, Kuri B, Smith C (2011) Pituitary Adenylate Cyclase-activating Peptide (PACAP) Recruits Low Voltage-activated T-type Calcium Influx under Acute Sympathetic Stimulation in Mouse Adrenal Chromaffin Cells. J Biol Chem 286:42459-42469. doi: 10.1074/jbc.M111.289389. PMID: 22009744.

15. Hill J, Lee SK, Samasilp P, Smith C (2012) Pituitary adenylate cyclase-activating peptide enhances electrical coupling in the mouse adrenal medulla. Am J Physiol Cell Physiol 303:C257-266. doi: 10.1152/ajpcell.00119.2012. PMID: 22592408.

16. Hodson DJ, Legros C, Desarmenien MG, Guerineau NC (2015) Roles of connexins and pannexins in (neuro)endocrine physiology. Cell Mol Life Sci 72:2911-2928. doi:10.1007/s00018-015-1967-2. PMID: 26084873.

17. Holman ME, Coleman HA, Tonta MA, Parkington HC (1994) Synaptic transmission from splanchnic nerves to the adrenal medulla of guinea-pigs. J Physiol 478 ( Pt 1):115124. PMID: 7965827.

18. Iwasa K, Oomori Y, Tanaka H (1999) Acetylcholinesterase activity, and neurofilament protein, and catecholamine synthesizing enzymes immunoreactivities in the mouse adrenal gland during postnatal development. J Vet Med Sci 61:621-629. PMID: 10423683.

19. Johnson MD, Grignolo A, Kuhn CM, Schanberg SM (1983) Hypertension and cardiovascular hypertrophy during chronic catecholamine infusion in rats. Life Sci 33:169-180. PMID: 6223191. 
20. Kandler K, Katz LC (1998) Coordination of neuronal activity in developing visual cortex by gap junction-mediated biochemical communication. J Neurosci 18:1419-1427. PMID: 9454851.

21. Kuri BA, Chan SA, Smith CB (2009) PACAP regulates immediate catecholamine release from adrenal chromaffin cells in an activity-dependent manner through a protein kinase

22. Livezey GT, Miller JM, Vogel WH (1985) Plasma norepinephrine, epinephrine and corticosterone stress responses to restraint in individual male and female rats, and their correlations. Neurosci Lett 62:51-56. PMID: 4069453.

23. Martin AO, Alonso G, Guerineau NC (2005) Agrin mediates a rapid switch from electrical coupling to chemical neurotransmission during synaptogenesis. J Cell Biol 169:503-514. doi: 10.1083/jcb.200411054. PMID: 15883200.

26. Matsuuchi L, Naus CC (2013) Gap junction proteins on the move: connexins, the

24. Martin AO, Mathieu MN, Chevillard C, Guerineau NC (2001) Gap junctions mediate electrical signaling and ensuing cytosolic $\mathrm{Ca} 2+$ increases between chromaffin cells in adrenal slices: A role in catecholamine release. J Neurosci 21:5397-5405. PMID: 11466411.

25. Martin AO, Mathieu MN, Guerineau NC (2003) Evidence for long-lasting cholinergic control of gap junctional communication between adrenal chromaffin cells. J Neurosci 23:3669-3678. PMID: 12736338. cytoskeleton and migration. Biochim Biophys Acta 1828:94-108. doi: 10.1016/j.bbamem.2012.05.014. PMID: 22613178.

27. Meda P (2017) Gap junction proteins are key drivers of endocrine function. Biochim Biophys Acta. http://dx.doi.org/10.1016/j.bbamem.2017.03.005. PMID: 28284720. 
28. Meda P, Perrelet A, Orci L (1979) Increase of gap junctions between pancreatic B-cells during stimulation of insulin secretion. J Cell Biol 82:441-448. PMID: 113418.

29. Mentis GZ, Diaz E, Moran LB, Navarrete R (2002) Increased incidence of gap junctional coupling between spinal motoneurones following transient blockade of NMDA receptors in neonatal rats. J Physiol 544:757-764. PMID: 12411521.

30. Moser T (1998) Low-conductance intercellular coupling between mouse chromaffin cells in situ. J Physiol 506 (Pt 1):195-205. PMID: 9481681.

31. Nassar-Gentina V, Pollard HB, Rojas E (1988) Electrical activity in chromaffin cells of intact mouse adrenal gland. Am J Physiol 254:C675-683. PMID: 3364553.

32. Petrovic J, Walsh PL, Thornley KT, Miller CE, Wightman RM (2010) Real-time monitoring of chemical transmission in slices of the murine adrenal gland. Endocrinology 151:1773-1783. doi: 10.1210/en.2009-1324. PMID: 20181796.

33. Ravier MA, Guldenagel M, Charollais A, Gjinovci A, Caille D, Sohl G, Wollheim CB, Willecke K, Henquin JC, Meda P (2005) Loss of connexin36 channels alters beta-cell coupling, islet synchronization of glucose-induced $\mathrm{Ca} 2+$ and insulin oscillations, and basal insulin release. Diabetes 54:1798-1807. PMID: 15919802.

34. Schwartz DD, Eikenburg DC (1986) Cardiovascular responsiveness to sympathetic activation after chronic epinephrine administration. J Pharmacol Exp Ther 238:148154. PMID: 2873235.

35. Slotkin TA (1986) Development of the sympathoadrenal axis. In: Gootman PM (ed) Developmental Neurobiology of the Autonomic Nervous System. Humana Press, Totowa, New Jersey, pp 69-96.

36. Smith CB, Eiden LE (2012) Is PACAP the Major Neurotransmitter for Stress Transduction at the Adrenomedullary Synapse? J Mol Neurosci 48:403-412. doi:10.1007/s12031-012-9749-x. PMID: 22610912. 
37. Stroth N, Kuri BA, Mustafa T, Chan SA, Smith CB, Eiden LE (2013) PACAP controls adrenomedullary catecholamine secretion and expression of catecholamine biosynthetic enzymes at high splanchnic nerve firing rates characteristic of stress transduction in male mice. Endocrinology 154:330-339. doi: 10.1210/en.2012-1829. PMID: 23221599.

38. Tank AW, Lee Wong D (2015) Peripheral and central effects of circulating catecholamines. Compr Physiol 5:1-15. doi:10.1002/cphy.c140007. PMID: 25589262.

39. Wakade AR (1981) Studies on secretion of catecholamines evoked by acetylcholine or transmural stimulation of the rat adrenal gland. J Physiol 313:463-480. PMID: 7277230.

40. Wakade AR (1998) Multiple transmitter control of catecholamine secretion in rat adrenal medulla. Adv Pharmacol 42:595-598. PMID: 9327972.

41. Watanabe T, Masuo Y, Matsumoto H, Suzuki N, Ohtaki T, Masuda Y, Kitada C, Tsuda M, Fujino M (1992) Pituitary adenylate cyclase activating polypeptide provokes cultured rat chromaffin cells to secrete adrenaline. Biochem Biophys Res Commun 182:403-411. PMID: 1310018.

42. Weinstock M, Razin M, Schorer-Apelbaum D, Men D, McCarty R (1998) Gender differences in sympathoadrenal activity in rats at rest and in response to footshock stress. Int J Dev Neurosci 16:289-295. PMID: 9785125.

43. Zaika OL, Pochynyuk OM, Kostyuk PG, Yavorskaya EN, Lukyanetz EA (2004) Acetylcholine-induced calcium signalling in adrenaline- and noradrenaline-containing adrenal chromaffin cells. Arch Biochem Biophys 424:23-32. doi:10.1016/j.abb.2004.01.012. PMID: 15019833. 

connexins on cell and tissue functions--an update. FEBS Lett 588:1186-1192. doi: 10.1016/j.febslet.2014.01.001. PMID: 24434539.

457

458

459 Acknowledgements: The author thanks Drs David J. Hodson, Jean Chemin and Michel G.

460 Desarménien for their critical and constructive reading of the manuscript.

461

462 


\section{Figure 1: Physiological remodeling of gap junctional signaling between chromaffin cells}

465 During adrenal postnatal development (left panel), the gap junctional coupling that is

466 prevalent at birth gradually decreases, as the sympathetic tone matures. This is associated

467 with a reduction in both the number of coupled chromaffin cells (from $>50 \%$ to $25 \%$ ) and the

468 strength of the electrical coupling, thus contributing to the maintenance of basal

469 catecholamine secretion. By contrast, in response to a stress episode (right panel), when a

470 huge catecholamine release is needed, the gap junctional signaling between chromaffin cells

471 is upregulated, leading to increased coupling strength and coupled cell number (from $25 \%$ to

$47280 \%$ ). Data collected from $[24,25,23,8,5,7,15,10]$.

473

Figure 2: Remodeling of gap junctional signaling in response to pathological conditions associated with sustained changes in the sympathetic tone

476 When sympathetic tone is impaired, as experienced by a splanchnectomy or the

477 pharmacological blockade of nAChRs (left panel), the gap junctional communication between 478 chromaffin cells increases. Conversely, upon a chronically heightened sympathetic tone, as 479 observed in hypertensive animals or mimicked by a sustained cholinergic stimulation (right 480 panel), the gap junctional coupling between chromaffin cells downregulates. Data collected 481 from $[25,7]$ and unpublished results. 


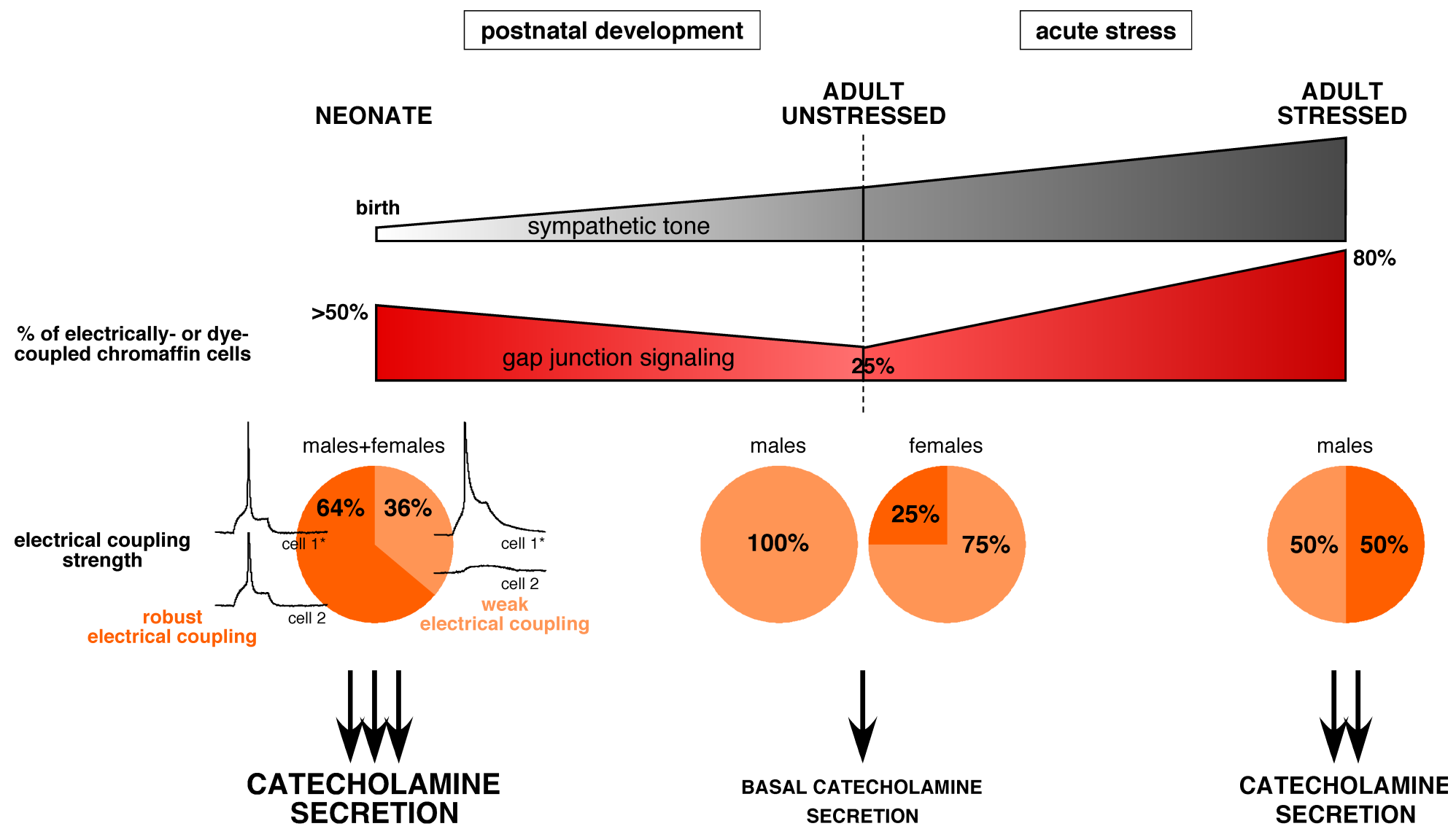

FIGURE 1 


\section{PATHOLOGICAL CONDITIONS}

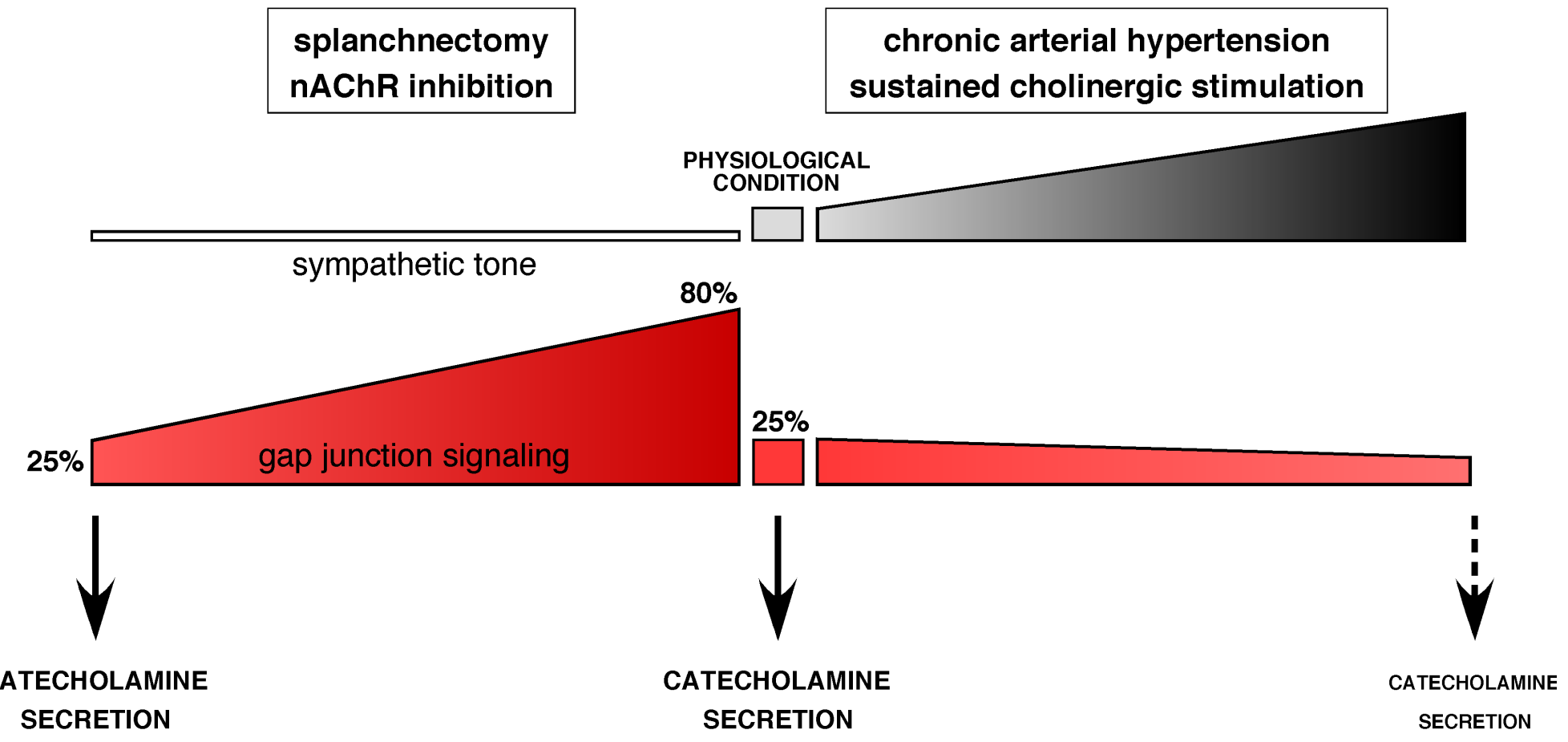

FIGURE 2 